\title{
PEMANFAATAN GEOGLE FORM UNTUK MENINGKATKAN PARTISIPASI PESERTA DIDIK DALAM EVALUASI BELAJAR BAHASA ARAB DI KELAS IXB MTS NEGERI 5KLATEN MASA PANDEMI SEMESTER GENAP TAHUN PELAJARAN 2020/2021
}

\author{
SRI SUWARNI DWI SAPUTRI \\ MTs Negeri 5 Klaten \\ E-mail : srisuwarnids71@gmail.com
}

\begin{abstract}
ABSTRAK
Penelitian ini dilakukan dengan tujuan untuk meningkatkan partisipasi peserta didik IXB MTs N 5 Klaten dengan jumlah 31 peserta didik.Teknik pengumpulan data yang digunakan adalah tes dan dokumentasi. Teknik analisis data yang digunakan adalah analisis deskriptif kuantitatif. Prosentase partisipasi peserta didik sebelum tindakan sebesar 61,00\%. Prosentase partisipasi peserta didik dalam mengikuti Evaluasi belajar di akhir siklus I sebesar 87,00\%. Sedangkan prosentase partisipasi peserta didik di akhir siklus II sebesar 100\%. Dengan demikian,dapat disimpulkan bahwa pemanfaatan geogle form dapat meningkatkan partisipasi peserta didik dalam mengikuti Evaluasi belajar Bahasa Arab di kelas IXB MTs Negeri 5 Klaten Semester Genap Tahun Pelajaran 2020/2021.
\end{abstract}

\section{Kata kunci: Google form, Partisipasi Peserta Didik, Masa Pandemi}

\section{PENDAHULUAN}

Di akhir bulan Desember 2019 seluruh dunia dihebohkan dengan kemunculan virusCovid-19 (Corona Virus Disease 2019) dan di awal Maret virus tersebut sudah sampai di negara Indonesiadengan cepat menularkan ke berbagai provinsi di seluruh negara Indonesia bahkan WHO (World Health Organization) mengatakan virus ini sebagai pandemi yaitu sebagai wabah penyakit yang serentak mewabah di berbagai belahan dunia. Pandemi Covid-19 sudah setahun lebih membuat segala pekerjaan dan pembelajaran dilakukan dari rumah (Work From Home). Kebijakan-kebijakan yangdiambil pemerintah untuk memutus mata rantai penyebaran Covid-19 adalah salah satunya meeminta lapisan masyarakat untuk semakin memiliki kesadaran pentingnya stay at home, mencuci tangan dengan sabun, physical maupun social distancing yakni proses pembatasan antar individu dengan individu yang lainnya secara fisik maupun sosial, sehingga pembelajaran tatap muka, dan memakai masker jika ada urusan penting yang memaksa untuk keluar rumah. Kondisi seperti ini tentulah tidak mudah dihadapi, apalagi untuk orang-orang yang tidak terbiasa atau yang tidak bisa bekerja dari rumah.

Kebijakan pemerintah meminta masyarakat untuk bekerja dan belajar bagi siswa mau tidak mau pembelajaran baik dilakukan di tingkat sekolah dasar, menengah bahkan perguruan tinggi otomatis akan dihentikan sementara sampai keadaan memungkinkan kembali diadakannya pembelajaran tatap muka. Ketika pembelajaran tatap muka secara langsung tidak dapat dilaksanakan perlu adanya cara dan upaya lain agar pendidikan dan pembelajaran dapat berlangsung yakni menggunakan kecanggihan teknologi yang ada sekarang. Bagi dunia pendidikan di Indonesia kebijakan memberlakukan pembelajaran secara daring (dalam jaringan/online) adalah bentuk nyata mendukung kebijakan pemerintah dalam memutus mata rantai penyebaran virus corona ini. Walaupun sebenarnya teknologi tidak dapat menggantikan peran tenaga pendidik seperti guru maupun dosen namun hal ini dinilai harus dilaksanakan untuk mengisi kekosongan yang ditimbulkan virus ini. Kemajuan teknologi saat ini dengan sangat cepat masuk hingga ke pedesaan, meskipun masih dalam batas-batas tertentu, misalnya media sosial seperti Facebook, WhatsApp maupun aplikasi media sosial lainnya.

Ada sebuah kalimat yang menarik kita cermati yaitu pidato Menteri Pendidikan dan Kebudayaan Republik Indonesia Nadiem Makarim pada upacara memperingati Hardiknas/Hari Pendidikan Nasional pada tanggal 2 Mei 2020, Mendikbud mengatakan ada hikmah dari adanya Pandemi Covid-19 ini, dimana kita bisa merasakan proses pembelajaran yang tidak 
dibatasi oleh ruang kelas, namun bisa dimanapun dan kapanpun. Dan ini adalah kali pertama dimana hampir seluruh tenaga pendidik di Indonesia melaksanakan proses pembelajaran lewat online atau daring. Memang kita sudah berada pada Era Revolusi Industry 4.0 yang menuntut kita untuk semakin pintar memanfaatkan teknologi dalam memudahkan pekerjaan yang kita lakukan. Namun, tidak bisa dipungkiri bahwa belum semua pihak siap menerima kondisi pembelajaran seperti ini, baik itu pihak Dosen/Guru sebagai tenaga pendidik maupun pihak mahasiswa/siswa sebagai peserta didik.

Ada fakta yang cukup mencengangkan bahwa guru yang mengikuti pelatihan penggunaan google form dalam pembelajaran beberapa peserta belum pernah menggunakan google form dalam proses pembelajarannya di kelas dan belum familiar dengan elektronik mail/e-mail.(Syarifuddin, 2020). Pemanfaatan teknologi informasi pada masa pandemi ini merupakan sebuah keniscayaan yang tidak dapat lagi ditolak keberadaannya. Teknologi selalu mengalami perubahan dan perkembangan pada setiap jaman. Teknologi berkembang karena adanya manusia. Keberadaan manusia dan teknologi tidak dapat dipisahkan, kedua faktor tersebut pasti saling berkaitan. Perkembangan teknologi dipengaruhi oleh manusia, sebaliknya manusia juga dipengaruhi oleh perkembangan teknologi. Saat ini berada pada perkembangan era globalisasi yang hampir menyeluruh di setiap poros dunia. Maka siapa yang tidak mampu mengikuti arus perkembangan teknologi dengan baik akan tergilas oleh jaman. Juga dengan teknologi semakin canggih semakin mudah juga pekerjaan yang dilakukan manusia. Imam Makruf mengutip pendapat Haag dan Keen bahwa teknologi informasi adalah seperangkat piranti yang membantu kita bekerja dengan informasi dan melakukan tugas yang berhubungan dengan pemerosesan informasi.(Makruf, 2009). Salah satu pemanfaatan teknologi informasi dalam pedidikan dan pembelajaran adalah dengan menggunakan aplikasi google form.

Dewasa ini ada anggapan proses pembelajaran bahasa Arab di Indonesia berjalan dengan lamban dan kurang berhasil bila dibandingkan dengan pembelajaran bahasa asing lainnya khususnya bahasa Inggris. Hal itu bisa dilihat dari lamanya waktu siswa yang dihabiskan dalam mempelajari bahasa Arab yakni dari tingkatan madrasah ibtidaiyah sampai perguruan tinggi namun standar kompetensi bahasa Arab belum dikuasai sepenuhnya. Hal ini perlu dipikirkan bersama khususnya tenaga pendidik baik sebagai guru maupun dosen bahasa Arab.(Ritonga, Nazir, dan Wahyuni, 2020)

Anggapan di atas dapat dikikis dengan cara memperbaiki cara mengajar bagi tenaga pendidik yang cenderung klasikal menjadi seiring dengan kemajuan teknologi dan informasi. Dalam hal ini teknologi informasi dapat digunakan dalam pembelajaran bahasa Arab menggunakan aplikasi google form (khususnya dalam pembuatan presensi kehadiran siswa dan evaluasi pembelajaran bahasa Arab).(Hasan, 2020)

Google Form adalah aplikasi administrasi survei yang termasuk dalam suite kantor Google Drive bersama dengan Google Dokumen, Google Sheets, dan Google Slides. Google form dewasa ini sangat banyak digunakan dalam survei maupun kelangkapan berkas data-data dalam acara webinar sebagai alat registrasi peserta maupun e-sertifikat webinar yang ada. Google form dalam adalah aplikasi untuk membuat formulir berbasis web dan mengupulkan jawabansecara online dan realtime. (Amalia 2019)

Keistimewaan dari aplikasi ini adalah sangat mudah digunakan meskipun pengguna pemula atau baru saja menggunakan aplikasi ini, fasilitas ini tidak dipungut biaya atau gratis, mudah dibagikan ke orang lain dan terakhir adalah mempunyai SpreadSheets hasil kuisioner yang sudah dikumpulkan dengan mudah mengolah semuanya tidak dipungut biaya layaknya di microsoft excell. Penggunaan media yang bervariasi juga akan membuat pembelajaran lebih menarik bagi peserta didik dan dapat menjauhkan sifat bosan dalam belajar khususnya Bahasa Arab.

Dalam dunia pendidikan sebuah pembelajaran tidak akan pernah dapat dinyatakan berhasil atau tidaknya selain menggunakan evaluasi atau penilaian. Apalagi sekarang ini penilaian tidak hanya bersifat kognitif tapi jua afektif dan psikomotorik. Evaluasi adalah sebuah proses yang dilaksanakan untuk mengumpulkan, menganalisis dan menyajikan informasi untuk 
digunakan dalam pengambilan keputusan dan pertimbangan dalam merencanakan kegiatan yang akan datang.(Matondang, 2019).

Sebuah kegiatan khususnya dalam pembelajaran selalu mementingkan tujuan begitu juga dengan evaluasi pembelajaran. Tujuan dilaksanakannya evaluasi pembelajaran adalah 1) menilai ketercapaian tujuan pembelajaran; 2) mengukur macam-macam aspek belajar yang bervariasi; 3) sebagai sarana untuk mengetahui apa yang ingin diketahui siswa; 4) memotivasi siswa; 5) menyediakan informasi untuk tujuan bimbingan dan konseling; dan 6) menjadikan hasil evaluasi sebagai dasar kurikulum.(Sunarya 2018, h. 68) Keenam tujuan evaluasi inilah yang seharusnya dipahami dengan betul oleh pendidik baik itu guru maupun dosen.

\section{METODE PENELITIAN}

Prosedur penelitian yang digunakan dalam penelitian ini adalah penelitian tindakan kelas. Menurut Ridwan (2020: 1), penelitian tindakan adalah penelitian yang berorientasi pada penerapan tindakan dengan tujuan meningkatkan mutu atau menyelesaikan masalah pada suatu kelompok subjek yang diteliti dan mengamati tingkat keberhasilan atau akibat tindakan yang dilakukan.

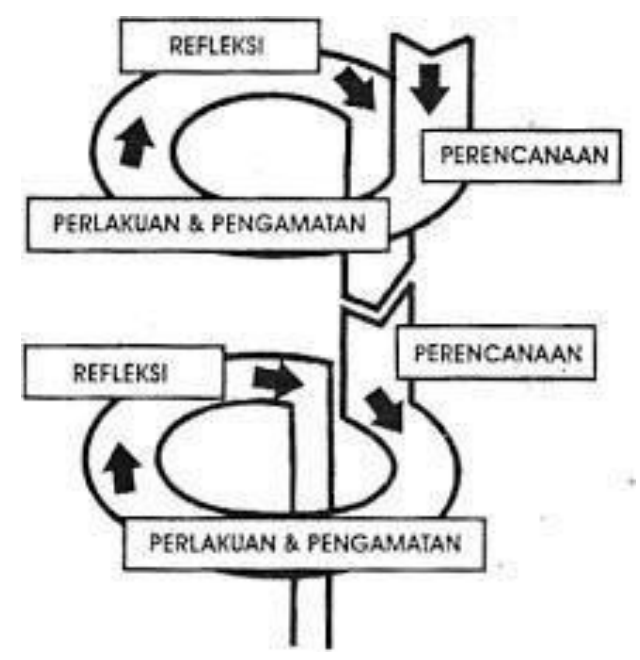

\section{Gambar 1. Siklus PTK menurut Kemmis (dalam Ridwan, 2020: 28)}

Penelitian dilaksanakan dalam dua siklus dengan masing-masing siklus terdiri dari tahap perencanaan, tindakan dan pengamatan, dan refleksi. Dalam siklus I, tahap perencanaan dimulai dengan penyusunan perangkat pembelajaran secara lengkap (RPP, bahan ajar, media, dan evaluasi), melakukan koordinasi dan sosialisasi pelaksanaan penelitian bersama rekan sejawat dan siswa, serta menyiapkan perangakat keras dan lunak untuk pelaksanaan pembelajarandaring melalui aplikasi E-Learning Madrasah yang dibuat oleh Kementerian Agama untuk mempermudah dan memperlancar pembelajaran dimasa pandemi ini. Selanjutnya pelaksanaan tindakan melalui pelaksanaan pembelajaran daring berbasis aplikasi E-Learning Madrasah yang didalamnya memuat semua unsur pembelajaran yang sangat lengkap menurut penulis. Namun untuk Evaluasi belajar penulis tid $a k$ hanya menggunakan aplikasi yang ada di E-Learning Madrasah agar ada variasi dalam evaluasi sehingga tidak membosankan peserta didik. Berbagai cara penulis lakukan untuk mendapatkan aplikasi yang berhasil untuk mendapatkan partisipasi peserta didik dalam evaluasi sehingga penulis mengetahui sejauh mana pemahaman peserta didik dalam pembelajaran daring ini.

Terakhir pelaksanaan refleksi, yaitu tahap di mana hasil pengamatan dan evaluasi tindakan yang telah dilakukan dalam pembelajaran dikumpulkan dan dianalisis. Hasil analisis kemudian direfleksikan dan digunakan sebagai dasar acuan merancang siklus II. Dalam siklus II, hasil refleksi siklus I digunakan untuk merencanakan dan merancang siklus 
II. Kegiatan siklus II meliputi perancangan perangkat pembelajaran daring, sosialisasi waktu pelaksanaan tindakan kepada peserta didik, dan persiapan hardware maupun software yang akandigunakan. Dilanjutkan dengan langkah pemberian tindakan dan pengamatan melalui kegiatan Evaluasi belajar dengan aplikasi Google Form. Sebagai kegiatan terakhir dalam siklus II akan dilaksanakan refleksi berupa analisis data yang telah terkumpul dan pengambilan kesimpulan pelaksanan penelitian tindakan.

Subjek penelitian ini adalah peserta didik kelas IXB MTs Negeri 5 Klaten dengan jumlah 31 peserta didik. Objek penelitian ini adalah partisipasi peserta didik dalam mengikuti Evaluasi dengan pemanfaatan geogle form. Teknik pengumpulan data dalam penelitian ini dilakukan dengan metode tes evaluasi hasil belajardan dokumentasi menggunakan aplikasi geogle form. Aspek yang menjadi tolok ukur keberhasilan dalam penelitian ini adalah peningkatan partisipasi peserta didik dalam mengikuti Evaluasi belajar dengan menggunakan aplikasi geogle form yang ditunjukkan dengan kenaikan prosentase partisipasi peserta didik yang mengikuti Evaluasi belajar dengan aplikasi geogle form.

Adapun kualifikasi prosentase partisipasi dilakukan dengan menghitung banyak peserta didik yangmenggikuti Evaluasi belajar yang dalam hal ini adalah Penilaian Harian Selanjutnya dihitung prosentase partisipasi dengan membanding banyak peserta didik yang berpartisipasi dibanding jumlah seluruh peserta didik.Kemudian dikualifikasi dengan menggunakan pedoman sebagai berikut:

Tabel 1. Kualifikasi Prosentase Partisipasi Peserta Didik

\begin{tabular}{lcc}
\hline No. & $\begin{array}{l}\text { Prosentase } \\
\text { Ketuntasan }\end{array}$ & Kualifikasi \\
\hline 1. & $81 \% \leq \mathrm{x} \leq 100 \%$ & Baik \\
\hline 2. & $61 \% \leq \mathrm{x} \leq 80 \%$ & Cukup \\
\hline 3. & $41 \% \leq \mathrm{x} \leq 60 \%$ & Kurang \\
\hline 4. & $21 \% \leq \mathrm{x} \leq 40 \%$ & Rendah \\
\hline 5. & $0 \leq \mathrm{x} \leq 20 \%$ & Sangat Rendah
\end{tabular}

Keterangan: $\mathrm{x}$ adalah prosentase partisipasi peserta didik.

\section{HASIL DAN PEMBAHASAN}

\section{Hasil Penelitian}

Hasil penelitian yang telah dilaksanakan dengan pemanfaatan geogle form dalam EvaluasiBelajar Bahasa Arab Kelas IXB MTs Negeri 5 Klaten. Berikut adalah sajian data hasil penelitiannya:

Tabel 2. Prosentase Partisipasi Peserta Didik Prasiklus, Siklus I, dan Siklus II

\begin{tabular}{llccc}
\hline No. & Keterangan & $\begin{array}{c}\text { Prasiklu } \\
\text { s }\end{array}$ & $\begin{array}{c}\text { Siklus } \\
\text { I }\end{array}$ & $\begin{array}{c}\text { Siklus } \\
\text { II }\end{array}$ \\
\hline 1. & Partisipasi Peserta Didik & 61,00 & 87,00 & 100
\end{tabular}




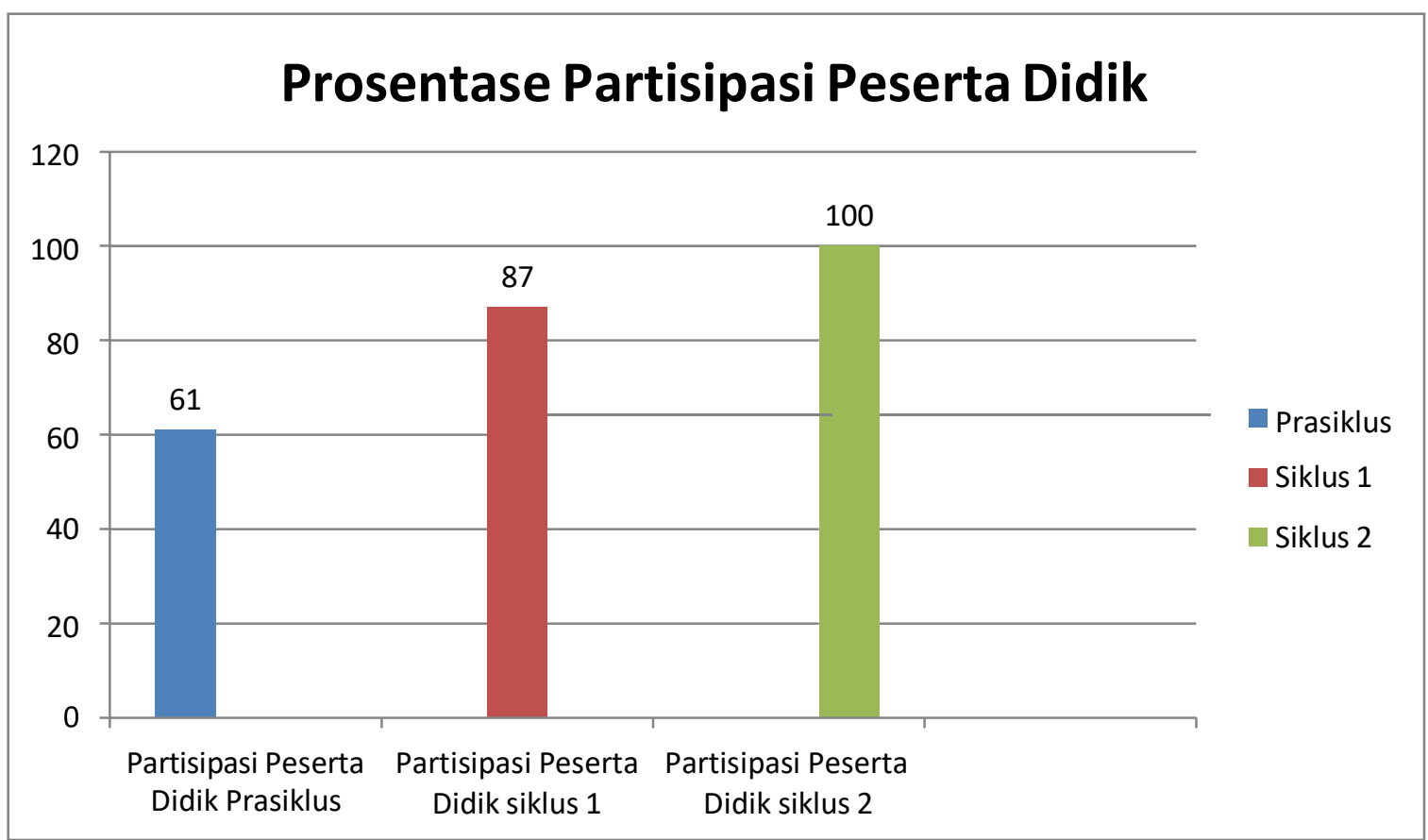

Gambar 2. Histogram Perbandingan Partisipasi Peserta Didik

Tabel 2 dan gambar 1 menunjukkan perbandingan Partisipasi Peserta Didik pada prasiklus, siklus I, dan siklus II. Dari data tabel di atas dapat terlihat bahwa partisipasi peserta didik dalam Evaluasi belajar ( Penilaian Harian 2) setelah dilakukan tindakan pemanfaatan google form dalam Evaluasi belajar mengalami peningkatan. Pada prasiklus partisipasi peserta didik $61,00 \%$ (cukup) meningkat menjadi $87,00 \%$ (baik) pada akhir siklus I, dan meningkat menjadi $100 \%$ (baik) pada akhir siklus II.

\section{Pembahasan}

Berdasarkan hasil penelitian yang sudah dilaksanakan pada peserta didik kelas IXB MTs Negeri 5 Klaten semester 2 tahun pelajaran 2020/2021 dengan pemanfaatan Geogle Form dalam Evaluasi Belajar ( Penilaian Harian 2 ) pembelajaran daring menunjukkan adanya peningkatan partisipasi peserta didik dari sebelum tindakan, siklus I, hingga siklus II. Data Prosentase peserta didik sebelum tindakan atau prasiklus yang diperoleh dari hasil Penilaian Harian 2 adalah $61,00 \%$ dengan kualifikasi cukup. Peningkatan prosentase partisipasi peserta didik setelah dilakukan tindakan pada siklus I dengan hasil $87,00 \%$ dengan kualifikasi baik pada siklus 1. Penelitian dilanjutkan dengan tindakan siklus II dengan perolehan prosentase partisipasi peserta didik meningkat menjadi $100 \%$ dengan kualifikasi baik.

Hasil penelitian ini sesuai dengan penelitian yang dilakukan sebelumnya oleh Sudarto tentang Strategi Pembelajaran Bahasa Arab Pada Masa Pandemi Covid - 19 Di MTsN 1 Pulang Pisau (2020) dimana pembelajaran dengan memanfaatkan Teknologi Dgitel pembelajaran menyebabkan partisipasi peserta didik lebih aktif. Hasil penelitian ini juga sesuai dengan penelitian yang dilakukan oleh Setyawan Harjanto (2020) tentang penelitian yang dilakukan dengan model Project Based Learning mata pelajaran Pemrograman Dasar siswa kelas X RPL $\mathrm{C}$ dapat meningkatkan partisipasi siswa dengan dibuktikan jumlah siswa yang aktif dalam pembelajaran berangsur-angsur naik dan pada siklus II jumlah tersebut telah memenuhi target yang telah ditetapkan meskipun pada awal siklus partisipasi siswa masih jauh dari target bahkan tidak ada partisipan sama sekali. Tindakan dalam penelitian ini berhasil karena guru belum pernah melakukan pemanfaatan Google Form dalam upaya meningkatkan partisipasi peserta didik dalam mengikuti Evaluasi Belajar, peserta didik antusias dan lebih tertarik pada Google Form dalam Evaluasi Belajar karena sangat mudah untuk mengaksesnya dan peserta didik dapat mengaksesnya di mana saja. 
Pembahasan tentang Pemanfaatan Google Form dalam Evaluasi Belajar Bahasa Arab atau Penilaian Harian di masa Pandemi meningkatkan partisipasi peserta didik dalam mengikutinya, sehinggadapat memperlancar Pembelajaran Bahasa Arab karena dengan lebih cepat mengetahui kemampuan pemahaman Peserta Didik. Google Form dapat meningkatkan kompetensi guru dalam mengevaluasi mata pelajaran bahasa Arab karena guru bertambah ilmu Teknologinya, Google Form mampu memberikan kemudahan dalam Evaluasi pembelajaran bahasa Arab dimasa pandemi ini karena aplikasi ini dapat juga digunakan untuk huruf-huruf Arab tanpa permasalahan yang berarti dan aplikasi ini tergolong ringan sehingga peserta didik dapat dengan mudah untuk mengaksesnya.

\section{KESIMPULAN}

Berdasarkan hasil dan pembahasan di atas, maka dapat disimpulkan bahwa pemanfaatan geogle form dapat meningkatkan partisipasi peserta didik dalam mengikuti Evaluasi belajar Bahasa Arabdi kelas IXB MTs Negeri 5 Klaten Semester Genap Tahun Pelajaran 2020/2021. Hal ini dapat dilihat dari hasil penelitian bahwa terjadi peningkatan Prosentase partisipasi peserta didik sebelum tindakan sebesar $61,00 \%$. Prosentase partisipasi peserta didik dalam mengikuti Evaluasi belajar diakhir siklus I sebesar 87,00\%.Sedangkan prosentase partisipasi peserta didik di akhir siklus II sebesar $100 \%$.

\section{DAFTAR PUSTAKA}

Amalia, Thoyyibatul. (2019). "Penggunaan Media Google Formdalam Evaluasi Pembelajaran Bahasa Arab Maharah Kitabah."

Arikunto, Suharsimi., dkk. (2008). Penelitian Tindakan Kelas. Jakarta: Bumi Aksara. Hasan, Hasan. (2020). Media Pembelajaran Bahasa Arab Dari Media Jadul Sampai Media Unggul. Amuntai: STIQ Amuntai Press.

Keputusan Menteri Agama Republik Indonesia, Nomor 183 Tahun (2019), Tentang Kurikulum Mata Pelajaran Pendidikan Agama Islam dan Bahasa Arab Pada Madrasah

Kosim, Nanang, Imam Turmudi, Novy Maryani, dan Abdul Hadi. t.t. "Pembelajaran Bahasa Arab Melalui Daring; Problematika, Solusi dan Harapan.”

Kunandar, (2009). Penelitian Tindakan Kelas Sebagai Pengembangan Profesi Guru. Jakarta:Rajawali Pers

Makruf, Imam. (2009). Strategi Pembelajaran Bahasa Arab Aktif. Semarang: Need's Press. Matondang, Zulkifli. (2019). Evaluasi Hasil Belajar. Medan: Yayasan Kita Menulis.

Ritonga, Mahyudin, Alwis Nazir, dan Sri Wahyuni. (2020). Pengembangan Model Pembelajaran Bahasa Arab Berbasis Teknologi Informasi \& Komunikasi dalam Dialektika Revolusi Industri 4.0. Yogyakarta: Deepublish.

Ridwan Abdullah, dkk. (2020). Panduan Praktis Penelitian Tindakan Kelas. Bandung: PT. Remaja Rosdakarya.

Saroh, Siti. (2019). Tutorial Membuat Media Pembelajaran 4.0. Surabaya: Pustaka Media Guru. Sani,

Sunarya, Tatang. 2018. Pembelajaran Mikro. Sumedang: UPI Sumedang Press.

Syarifuddin, Syarifuddin. (2020). "Bimbingan Penggunaan Google Form Untuk Pembelajaran IPS Pada Madrasah di Banua Enam." Manhaj: Jurnal Penelitian dan Pengabdian Masyarakat 9 (1): 45-58. http://dx.doi.org/10.29300/mjppm.v9i1.3002. 